UDC 141.319.8:1(430)(470+571)(091)

\author{
V. S. VOZNYAK ${ }^{1 *}$, N. V. LIPIN²* \\ 1* Drohobych Ivan Franko State Pedagogical University (Drohobych, Ukraine), e-mail volodimir.voznyak@gmail.com, \\ ORCID 0000-0002-6877-3785 \\ ${ }^{2 *}$ Kyiv National University of Trade and Economics (Kyiv, Ukraine), e-mail pinli@ukr.net, ORCID 0000-0003-0940-088X
}

\title{
EDUCATION LIKE BREACH BETWEEN PAST AND FUTURE
}

Purpose. The article aimed at comprehending the phenomenon of education in its anthropological content, by comparing two versions for the analytics of the crisis state in education, given by Hannah Arendt and Evald Ilyenkov. Theoretical basis. For implementing this task, the method of in-depth reflexive reading of texts is used, when traditional academic concepts are considered in a new context determined by the analytics of real social problems. In this case, we are talking about the development of thinking not only as a cognitive ability but as an ethical and ontological feature of a human being. In that event, thinking arises through its invisible belonging of one person to many others that both Arendt and Ilyenkov ascertain. Originality. Originality of the article is to identify the anthropological dimension of education and to establish the negative influence of such ways in organizing the educational process while it is under the dictation of current circumstances. The justification for this thesis is presented by identifying the consonance of the educational concepts from Hannah Arendt and Evald Ilyenkov. Conclusions. The opposition between action and thinking, revealed by Hannah Arendt, cannot be understood as a divorcement of thinking from reality, since another man appears to be the original reality for a person, namely, in thinking a person enters the space of a meeting with another man, put himself into another person's mind and with this firstly attains his place in the world, becoming himself, acquiring the image of a man. So perceived education does not become manipulative training, but it is a real birth of a subject as creating himself. Undermining of the authority in the modern world is accompanied by the searching new forms in structuring the common space of human endeavor, which is possible when the educational status is determined by its attitude to the world rather than by the social environment. The authority of a teacher is effective when he relies on his responsibility for the world into which he introduces the child and which opens to him. Responsibility for peace and the resulting authority is associated with love for the world. Only with sufficient love for the world, a person is capable of taking responsibility for it.

Keywords: man; education; thinking; society; authority; responsibility for the world

\section{Introduction}

The creativity of Hannah Arendt is most often associated with the problems of evil and violence and the analytics of the totalitarianism phenomenon. However, it is increasingly noticed that deepening of this issue deduces her thought to the problems of thinking: just recall her thesis, which sounds like some conclusion: Eichmann's inability to think (Arendt, 2008, p. 81), a report on the banality of evil (Arendt, 2008, p. 376) is headlined. Therefore, although she positions herself as a political thinker, one appeals to her heritage at the beginning of the 21st century in connection with the comprehension of the crisis in education. Moreover, this is a worldwide trend (Hodgson, Vlieghe, \& Zamojski, 2018; Korsgaard, \& Aldinger, 2018; Shchyttsova, 2019; Vlieghe, \& Zamojski, 2019). The situation of a person in the modern world is directly related to the understanding of thinking (Mamardashvili, 1992, p. 119), which draws special attention to the field of education. After all, exactly in the space of education such a universal human ability as thinking should purposefully develop, this is ascertained by such thinkers as Friedrich Nietzsche (1996, p. 381) and Evald Ilyenkov (2002). To some extent, they represent two poles of the human situation: the dominant of life and the dominant of thought. Comprehension of this confrontation is seen as productive for understanding the crisis of education in its anthropological dimension when not only professional skills but the human image itself is in the spotlight. 
From our point of view, a person enters the human world through the development of thinking. The child begins to think from an early age, coming together with adults into the world of human culture. Life, especially school life, does not oppose to thinking. Rather, on the contrary, thinking should be immanent to the life of education. Then education ceases to be a preparation for adulthood and becomes a common (students and teacher) cause of thinking. The gap between thinking and activity, the invisible world and the phenomenal world, public and private space, on which Arendt focuses her attention, translates into an understanding of education as preparation for life (Biesta, 2010), as a result, there is a danger of authoritarian manipulation. When comparing the statement of the Arendt's education problems and the position of the educator described by Kierkegaard (Korsgaard, \& Aldinger, 2018), the question arises: how can we educate our children to become independent and critical beings, at the same time hoping that they will become so critical to have nothing common with us. At the same time, it is worth noting the trap into which the older generation falls, expecting the execution of their attitudes and thereby turning the educational process into a manipulation (Freire, 2017).

As we see it, the formulation of this problem is related to the contradiction recorded by Arendt: a person lives among people and the sphere of publicity is important for him, but distortion into the sphere of publicity is the reason for an escape from subjectivity. As a result, active life and leveling of the contemplative life begin to dominate, with which Arendt (1989) associates thinking (p. 23). She associates the evil of totalitarianism with a lack of thinking. Moreover, it is interpreted not in a cognitive sense, but as the ability to see the world through the eyes of another person. E. Minnich (2016) continues to develop this direction. She enhances Arendt's approach to thinking asserting the "evil of banality": in a situation of the thoughtlessness of everyday life, a type of evil ("extensive evils") develops, which is very difficult to resist due to its anonymity and mass character.

Shchyttsova (2019) expressed the broad context of problematics, on the base of H. Arendt's texts she highlights the relationship between education and political life in modern societies and notes the antidemocratic, elitist aspect in her interpretation of natality: "the education based on the so-interpreted principle of natality cannot contribute the formation of a democratic community, an ethos of democratic solidarity" (p. 17). She notes the critical re-reading of Arendt's works, which began in the second half in the 80s of the 20th century in European space and speaks about the ambivalence of conclusions, wondering how to read Arendt today. How to read Arendt's texts with students are issues of particular relevance: if we assume that we want to be equally anti-authoritarian as Arendt was anti-totalitarian author, and we want to be equally antineoliberal as Arendt was humanistic (Shchyttsova, 2019, p. 18).

One of the opportunities for such a reading was developed by Hodgson, Vlieghe, and Zamojski (Hodgson, Vlieghe, \& Zamojski, 2018; Vlieghe, \& Zamojski, 2019). These authors assert that one of the important points in the comprehension of education by Hannah Arendt is the actualization of "love for the world" as non-indifference and interested attitude: "Education is an interaction between the generations which is first and foremost concerned with disclosing the world (rather than with learning)" (Vlieghe, \& Zamojski, 2019, p. 522). In other words, the dominant of freedom in education is connected with an interest to the world that is worth the effort to study with the new generation. Then learning is a constant attempt to make "educational love" the guiding principle of student-teacher relations, not only they possess subjectivity (autonomous freedom), but a "third actor" appears (Voznyak, 2014): the very heart of the matter becomes leading. The dominant of the core subject (a developing part of 
the world) presupposes the continued authority emanating from a lovingly cultivated world rather than the power of a human-teacher.

\section{Purpose}

The article offers the opportunity to read Hannah Arendt's ideas in the optics of an active approach to the problem of thinking. Prospectivity of this philosophical direction is presented in the actualization of the ideas by Ewald Ilyenkov in the European intellectual space, which was started in the 90s of the 20th century by David Bakhurst (1991), later by Vesa Oittinen (2014) and is being actively continued today (Lotz, 2019; Vivaldi, 2017).

Evald Vasilievich Ilyenkov (1924-1979) is the outstanding Soviet philosopher of the twentieth century. He was a contemporary of $\mathrm{H}$. Arendt and interpreted the problems of education, thinking and human development in a man from a different perspective and in line with another philosophical tradition. If Arendt's philosophizing can be characterized as continuations of the Kantian tradition, then Ilyenkov was a Marxist, but, let's say so, in the Hegelian sense. In other words, he was a conscious and deep dialectician. Belonging to this direction of philosophical thought was expressed in his works, which are devoted to various aspects of the aesthetic nature of fantasy, the theory of the ideal development of a creative personality and the problems of pedagogy.

The Ilyenkov's concept of thinking moves in line with the classical philosophical tradition, which was substantively disclosed by Gennadiy Lobastov (2012) and Sergey Mareev (2015), this is its dignity and advantage compared to new-fangled conversations about thinking and its nature. Bakhurst (1991, p. 174, 186), and Levant (2012), and Vivaldi (2017, p. 186) stand Ilyenkov's philosophy in connection with the history of Western philosophy, noting the importance of his approach to the problem of ideal.

\section{Statement of basic materials}

From the viewpoint of Arendt (1961), "essence of education is natality, the fact that human beings are born into the world" (p. 174). Appeal to the phenomenon of birth (natality) in the context of education and upbringing allows us to consider them as preparation for creating a new one. The child, the younger generation is perceived by H. Arendt (1998) as a chance to renew, implement a new initiative in the old world. "The new beginning inherent in birth can make itself felt in the world only because the newcomer possesses the capacity of beginning something anew, that is, of acting" (Arendt, 1961, p. 9). And although a person is conditioned by the world of things created by him, natality as a fundamental premise for human existence is most closely bonded not with labor and creation, but with a deed. A characteristic feature of such an action as the deed is that it "goes on directly between men without the intermediary of things or matter" (Arendt, 1961, p. 7). Since politics is a way of human existence among other people, "since the action is the political activity par excellence" (Arendt, 1961, p. 9), and natality is a central category of political life.

The problem is that, in H. Arendt's (1961) opinion, upbringing should not play any role in politics, because in the political sphere we are dealing with equals, i.e. with those that have already been brought up (p. 177). In the field of education, in Arendt's opinion, it is out of the question the equality between a child and an adult. The relationship between a teacher and a student should be determined by the authority.

In that moment in Arendt's discussion of education, there is a temptation to interpret relations between participants in the educational process as authoritarian ones. It should be noted that 
Arendt herself provides some reason for such an interpretation of authority-based relations. So, for example, in her work "What is authority?", she writes: "authority is whatever makes people obey" (Arendt, 1961, p. 92). And although authority means "such obedience in which people retain their freedom" (Arendt, 1961, p. 93), authoritarian relations, as H. Arendt (1961) asserts, unfold in the absence of a "common intelligence" (p. 93).

Authority is incompatible with persuasion, which presupposes equality

and works through a process of argumentation. Where arguments are

used, authority is left in abeyance. Against the egalitarian order of per-

suasion stands the authoritarian order, which is always hierarchical. If au-

thority is to be defined at all, it must be in contradistinction to both coer-

cion by force and persuasion through arguments. (Arendt, 1961, p. 93)

Comprehending the foundations of the crisis in American education in the 1950s, H. Arendt considered the loss of a teacher's authority the most significant among them. Such a loss happened by two reasons: firstly, because the teacher turned into a skilled worker who simply informs the student about his subject, but does not take responsibility for the world (Arendt, 1961, p. 189). Secondly, the deeper cause in the collapse of authority was the preceding crisis of tradition and religion. In the old days, authority was built on the basis of tradition. In the 50-60s of the last century, the bridge between the past and the future, which was a tradition, broke down. Following it, the authority resting on the automatism of prejudices, also collapsed.

In the contemporary world, which is not structured by authority and is not supported by tradition, education cannot completely abandon them. However, it would be a mistake to understand the need for educational authority as a call for authoritarian relations. From our viewpoint, such relationships are an obstacle to developing thinking. Authoritarian relations enshrine a certain place for a person in hierarchical relations. But, as it will be shown later, thinking is just a way to overcome the limitations of any socially fixed place. And thanks to such ability as imagination, a person could be in the place of any other person, look at the world through his/her eyes. Moreover, for the development of thinking, imagination, as the ability to look at the world through other eyes, is constitutive one. It is also significant for the revival of tradition, as the ability to look at the world through the eyes of people of other eras and cultures.

In this regard, it is necessary to understand that restoring the authority and the appropriate attitude toward the past requires dividing the education from the rest of the spheres in the world. This is necessary "in order to apply to it alone a concept of authority and an attitude toward the past which are appropriate to it but have no general validity and must not claim a general validity in the world of grown-ups" (Arendt, 1961, p. 195). In fact, we are talking about freeing the activity of education and upbringing from the influence of society and politics, going beyond the prevailing principles and norms in them.

So, education must not be completely defined by that place which it, as a social institution, occupies in the society. In this angle, it does not have a place, it is a question about education as the "island of utopia". That is to say, the place of education is defined not by the social environ- 
ment, but by its attitude to the world. The authority of the teacher is inseparable from his responsibility for the world, into which he introduces a child and shows it to him. The teacher should not limit by the learning of "art of living", because "the function of the school is to teach children what the world is like and not to instruct them in the art of living" (Arendt, 1961, p. 195). Responsibility for peace and the resulting authority is associated with love for the world. Only with sufficient love for the world, a man is responsible for it.

Thus, in education, authority can only be personal and conditioned by responsibility for the world, the ability to demonstrate it to children. The significance of personal authority in education lies in the fact that it allows you to live without violence, power, and strength. Where "force is used, authority itself has failed" (Arendt, 1961, p. 93). And although "authority is whatever makes people obey" (Arendt, 1961, p. 103), it presupposes "an obedience in which people retain their freedom" (Arendt, 1961, p. 106). We believe that the authority of a teacher can be defined as "enforcement" to freedom which is possible through the discovery of the world. In this case, the freer the subjects of the pedagogical process become, the lesser role the authority plays in the field of education. Despite the fact that, according to Arendt, upbringing does not imply the possibility of equality, exactly it should be the goal that determines the student and teacher relationship. We can agree with the J. Rancière's (1991) opinion that equality in the ability to think is at the same time essential for the possibility of education as liberation: "We know that it is this that defines the stultifying vision of the world: to believe in the reality of inequality, to imagine that the superiors in society are truly superior..." (p. 108).

The world opens to a man not in loneliness, but in life together with other people. "Inner freedom" results as a consequence of the obtained world's freedom experience. As H. Arendt (1961) wrote, for the first time we feel freedom and its opposite "in our intercourse with others, not in the intercourse with ourselves" (p. 148). In addition to this, we get and the experience of our own "I" through the experience about another person. The relation to oneself, in which a person's knowledge of inner freedom is possible, is mediated by the relation to another. So, freedom is not individual in its inherent, but a social one. Firstly, we perceive freedom not despite, but because of existence among people. And if freedom is the freedom to act, then education is such pre-political "the scene for action and speech" (Arendt, 1961, p. 148), where the younger generation learns the reality of freedom.

Obviously, freedom is associated with the superfluity of human existence. It is not dependent on external or internal violence. Entrance into the world, which occurs in education, is liberation from the dictate of the empirical environment, transcending from here (space) and now (time) to the sphere where all temporal and spatial distances are destroyed, into the breach between the past and the future, i.e. into thinking. According to H. Arendt, thinking has no place, it is everywhere, and therefore nowhere. It always "falls out of any kind" and interrupts the automatism of daily living. Thinking carries a man to "into some never-never land, the land of invisibles" (Arendt, 1981, p. 85). In thinking, it is possible to restore the connection between the past and the future, to revive the tradition. It unfolds in a situation of lack of tradition and authority, outside of any hierarchies and predetermined outcome. "Each new generation, every new human being, as he becomes conscious of being inserted between an infinite past and an infinite future, must discover and ploddingly pave anew the path of thought" (Arendt, 1981, p. 210). Thus, birth and the freedom associated with it for own realization should "pave" the path of thought.

Education introduces the child into the world, revealing the breach between the past and the future. Thinking originates in this breach, in breaking the ordinary course of life. This breach is a 
"small non-time-space" (Arendt, 1961, p. 13) compels a person to transcend his own finitude and thereby constitute the sphere of the spirit, trample down space through the activity of thinking "the trains of thought, of remembrance and anticipation, save whatever they touch from the ruin of historical and biographical time" (Arendt, 1961, p. 13). So, thinking unfolds in a situation of disruption, interruption of the ordinary course of life. In a situation of lack of thinking, continuity between generations and the preservation of what is generated by human activity becomes impossible, and it is destroyed by it.

What H. Arendt calls "the invisible world of thinking", "non-time-space", E. Ilyenkov describes it as an ideal form that does not exist as a finished result.

It is that which is not, together with that which is, that which does not ex-

ist in the form of an external, sensuously perceived thing but at the same

time does exist as an active faculty of man. It is being, which is, howev-

er, not-being, or the effective being of the external thing in the phase of

its becoming in the activity of the subject, in the form of its inner image,

need, urge, and aim. (Ilyenkov, 2008, p. 264)

The ideal thinking exists as a certain bodiless form, as the omnipotent soul of things which remains itself in various bodily incarnations. But simultaneously it does not coincide with any of them. "A form of which it cannot be said where exactly it 'exists'. Everywhere and nowhere in particular" (Ilyenkov, 2012, p. 180). The ideal one is the "taken off form", the form of a thing outside of the thing itself, namely, in the form of human activity. "In itself, the ideal is the socially determined form of man's life activity corresponding to the form of its object and product" (Ilyenkov, 2008, p. 261). However, the ideal in itself moves further: "the ideal is only there where the form itself of the activity corresponding to the form of the external object is transformed for man into a special object with which he can operate specially without touching and without changing the real object up to a certain point" (Ilyenkov, 2008, p. 278).

Then a person does the activity in an ideal plan and with an ideal plan. Actually, this is how thinking works: with an ideal plan, transforming the form.

As G. Lobastov (2012) notes a pure form of activity opposing any form of objective reality is, according to Ilyenkov, thinking. In his schemes, categories any and each thing is represented and seen. Thinking is "an ideal reproduction of reality in its own universal forms, and this universal form is a form of one's own activity" (Lobastov, 2012, p. 384). The universal ideal forms of man's activity learned from the history of human existence are essential for the formation of individual abilities, including thinking.

E. Ilyenkov did not bypass the problems of the formation of thinking in ontogenesis, actively participating in the famous Zagorsk experiment on the training and education of blind-deafmute children. Thinking (as well as other abilities) germinates and grows in a child in the process of his inclusion in a jointly divided activity with adults, and then with peers. In the process of such activities, the child learns to master the ideal form, objectified in things, and had been created by man and for man. Within this activity, the child immediately focuses his perception on the mean- 
ing of the objects included in it. These are both household goods and toys. Acquiring a language, the child can already "work" with the ideal form per se, "inside him", using logical categories that are embedded in the structure of the language (speech). G. Lobastov (2012) notes that in the substantively-transformative activity "a person's ability is formed to reproduce the scheme of his activity with things beyond these things themselves, but in some other material" (p. 19). Thinking as such finds itself only in acts of an objective shift "in human work methods, therefore, in acts of shift, changes in the form of the thing itself, in the disclosure in its composition of new, hitherto unknown parameters and characteristics" (Lobastov, 2012, p. 38).

In a perfect form, the social nature of a person is represented, or, by H. Arendt's words, the fact that a person exists among other people. Therefore, thinking and activity open the world rather than just the environment of existence, because they allow you to look around with the eyes of other people, to be in their place. Learning to think, educating the mind, in this case, is the development of the ability to look at things from the standpoint of the human race.

Consciousness only arises where the individual is compelled to look at himself as if from the side, as if with the eyes of another person, the eyes of all other people - only where he is compelled to correlate his individual actions with the actions of another person, that is to say, only within the framework of collectively performed life-activity. (Ilyenkov, 2012, p. 187)

In this context, it is understandable that thinking is not just, what Arendt believes, should be returned to the world through judgment.

If thinking, the two-in-one of the soundless dialogue, actualizes the difference within our identity as given in consciousness and thereby results in conscience as its byproduct, then judging, the by-product of the liberating effect of thinking, realizes thinking, makes it manifest in the world of appearances, where I am never alone and always much too busy to be able to think. (Arendt, 1968, p. 189)

According to Arendt, politics is the primary area in the return of thinking to the world. It is within it a deed is possible. In accordance with the dividing the social and political spheres of human existence, the first appears to be deprived of the liberating force of thinking. But the problem in the return of thinking to the world is seen in a slightly different way if we assume that 
thinking for the first time only arises in the world. From this perspective, following G. Hegel, E. Ilyenkov solved this problem.

From the E. Ilyenkov's (2006) viewpoint, the development of the personality himself is nothing more than the development of the ability to look at the world through the eyes of the human race. In E. Ilyenkov's opinion, the emphasized ability is directly related to the work of the mind and imagination. He defined them as the ability to see things through the eyes of another person, through the eyes of all other people, through the eyes of mankind (Ilyenkov, 2006, p. 215). Inability to put oneself in the place of another person, i.e. lack of imagination is the cause of the destruction of the world as space "between people" (Arendt, 1968, p. 4). The lack of imagination distorts the world that the younger generation is encountering. This happens because, firstly, "broad-mindedness" and its universality are directly related to the ability to take the place of another person, to accept his point of view and his judgment (Arendt, 1989, p. 43; Ilyenkov, 2006, p. 215).

Secondly, the undeveloped ability of imagination is often expressed in the inability to see reality and compensated by unbridled fantasies. For education and upbringing, the lack of imagination leads to the fact that thinking is replaced by a collection of finished knowledge. "A person deprived of imagination, or rather with an undeveloped imagination, sees only what he already knows in advance in the world around him, what is verbally recorded in his mind, in his psyche" (Ilyenkov, 2006, p. 225). Without the ability of imagination, a person is only able to recreate swotted information and act in strict accordance with it.

With the help of imagination, thinking leaves its isolation from other people, correlates itself with their standpoints. And although, as H. Arendt (1989) insists, thinking takes place in isolation, "it still goes on in isolation, but by the force of imagination, it makes the others present and thus moves in a space that is potentially public, open to all sides" (p. 43).

\section{Originality}

Originality of the article is in comprehending the anthropological dimension of education when it reveals not only a professional orientation, but it is seen as a strategy for constituting a person, developing his image. This semantic aspect is present in the German word Bildung and neglect of this component is detrimental to the education system, which is explicated through a comparison of the concepts in the education of Hannah Arendt and Evald Ilyenkov.

\section{Conclusions}

Thus, in thinking endowed with the ability of imagination, public space and essential openness, the nature of a man, unfolds. Thinking is isolated on the individual's side, but it is a social ability. For good reason, at least two people are required to dialogize among themselves in order to realize it. The value of thinking in education is defined by its invisible belonging of one person to many others. Therefore, the task of education is insight into the world to new generations, the world that is not directly given to the sensory organs, which is invisible, but it holds everything visible. It is exactly the space between people in which a man is truly born as a man, i.e. begins to see the world through the eyes of all other people. In this sense, education is enlightenment, gaining the ability to see and act.

In thinking, a person, remaining himself, enters the space of multiplicity. He puts himself into the place of another person and with this firstly finds his place in the world. Such thinking is both critical and caring (ethical). In it, using the creative ability of imagination, a person not only thinks together with others, but also feels together (sympathizes) with others. 
Education can teach to think if it appears as such a common cause in which all actors of the pedagogical process are involved. The teacher is the guide of the child to the world. But you can only show the world to someone who can and wants to see it. In order for education to be a common cause, all its participants must strive to achieve equality. After all, public space makes sense as a space of concern for a common interest, as a space of liberation from the tendency to impose their interest on others and the world as a universal one. In thinking, which does not have a visible result, in fact, there is one very important result - this is the subjectivity, humanity of those who think. One can think only being a "citizen of the world", a representative of the human race. Realizing his common cause in accordance with its essence, an individual (a child and an adult) introduces himself into the appropriate image and likeness of a person.

\section{REFERENCES}

Arendt, H. (1961). Between Past and Future. New York: Viking. (in English)

Arendt, H. (1968). Men In Dark Times. New York: Harcourt, Brace. (in English)

Arendt, H. (1981). The Life of The Mind. Harvest Book. (in English)

Arendt, H. (1989). Lectures on Kant's Political Philosophy. R. Beiner (Ed.). University of Chicago Press. (in English)

Arendt, H. (1998). The Human Condition. Chicago: University of Chicago Press. (in English)

Arendt, H. (2008). Banalnost zla. Eykhman v Ierusalime. Moscow: Evropa. (in Russian)

Bakhurst, D. (1991). Consciousness and Revolution in Soviet Philosophy: From the Bolsheviks to Evald Ilyenkov. Cambridge: Cambridge University Press. (in English)

Bazaluk, O., Fatkhutdinov, V., \& Svyrydenko, D. (2018). The Potential of Systematization of the Theories of Education for Solving of Contradictions of Ukrainian Higher Education Development. Studia Warmińskie, 55, 63-79. DOI: https://doi.org/10.31648/sw.3062 (in English)

Biesta, G. (2010). How to exist politically and learn from it: Hannah Arendt and the problem of democratic education. Teachers College Record, 112(2), 556-575. (in English)

Freire, P. (2017). Pedagogy of the Oppressed. London: Penguin Books. (in English)

Hodgson, N., Vlieghe, J., \& Zamojski, P. (2018). Education and the Love for the World: Articulating a post-critical educational philosophy. Foro de Educación, 16(24), 7-20. DOI: https://doi.org/ 10.14516/fde.576 (in English)

Ilyenkov, E. V. (2002). Shkola dolzhna uchit myslit. Moscow: Moskovskiy psikhologo-sotsialnyy institut. (in Russian)

Ilyenkov, E. (2006). Ob idolakh i idealakh. Kyiv: Chas-Krok. (in Russian)

Ilyenkov, E. V. (2008). Dialectical Logic: Essays on its History and Theory. H. C. Creighton, Trans. New Delhi: Aakar Books. (in English)

Ilyenkov, E. (2012). Dialectics of the Ideal. Historical Materialism, 20(2), 149-193. DOI: https://doi.org/ 10.1163/1569206x-12341248 (in English)

Korsgaard, M. T., \& Aldinger, M. M. (2018). The Educator's Diary: Arendt and Kierkegaard on Progressivism and the Educational Relation. Educational Theory, 68(4-5), 513-527. DOI: https://doi.org/10.1111/edth.12325 (in English)

Levant, A. (2012). E. V. Ilyenkov and Creative Soviet Theory: An Introduction to "Dialectics of the Ideal". Historical Materialism, 20(2), 125-148. DOI: https://doi.org/10.1163/1569206x-12341247 (in English)

Lobastov, G. V. (2012). Dialektika razumnoy formy i fenomenologiya bezumiya. Moscow: Russkaya panorama. (in Russian)

Lotz, C. (2019). Finding Evald Ilyenkov: How a Soviet philosopher who stood up for dialectics continues to inspire. MRonline. Retrieved from https://mronline.org/2019/08/31/corinna-lotz-finding-ilyenkov-how-a-sovietphilosopher-who-stood-up-for-dialectics-continues-to-inspire/ (in English)

Mamardashvili, M. (1992). Soznanie i tsivilizatsiya. In Kak ya ponimayu filosofiyu (pp. 107-121). Moscow: Progress. (in Russian)

Mareev, S. N. (2015). Zhit filosofiey. Moscow: Akademicheskiy proekt. (in Russian)

Minnich, E. K. (2016). The Evil of Banality: On the Life and Death Importance of Thinking. Rowman \& Littlefield Publishers. (in English)

Creative Commons Attribution 4.0 International

doi: https://doi.org/10.15802/ampr.v0i17.206722 
Nietzsche, F. (1996). Chelovecheskoe, slishkom chelovecheskoe. In Sochineniya (Vol. 1, pp. 231-490). Moscow: Mysl. (in Russian)

Oittinen, V. (2014). Evald Ilyenkov, the Soviet Spinozist. In Dialectics of the Ideal (pp. 107-122). Leiden: Brill. DOI: https://doi.org/10.1163/9789004246928_006 (in English)

Rancière, J. (1991). The ignorant schoolmaster: Five lessons in intellectual emancipation. K. Ross, Trans. Stanford University Press. (in English)

Shchyttsova, T. (2019). Which crisis? Whose rationality? Rethinking Arendt's concept of natality in view of contemporary challenges for university education. Ideology and Education in Post-Soviet Countries, 2(13), 8-19. (in Russian)

Vivaldi, G. A. (2017). Rethinking Soviet Marxism: The Case of Evald Ilyenkov. Historical Materialism, 25(2), 180-195. DOI: https://doi.org/10.1163/1569206x-12341522 (in English)

Vlieghe, J., \& Zamojski, P. (2019). Out of Love for Some-Thing: An Ontological Exploration of the Roots of Teaching with Arendt, Badiou and Scheler. Journal of Philosophy of Education, 53(3), 518-530. DOI: https://doi.org/10.1111/1467-9752.12375 (in English)

Voznyak, V. (2014). In search of "the third subject" of educational process. The Kazakh-American Free University Academic Journal, 6, 109-116. (in English)

\section{LIST OF REFERENCE LINKS}

Arendt H. Between Past and Future. New York : Viking, 1961. 246 p.

Arendt H. Men In Dark Times. New York : Harcourt, Brace, 1968. 288 p.

Arendt H. The Life of The Mind. Harvest Book, 1981. 521 p.

Arendt H. Lectures on Kant's Political Philosophy / ed. by R. Beiner. University of Chicago Press, 1989. 174 p.

Arendt H. The Human Condition. Chicago : University of Chicago Press, 1998. 349 p.

Арендт Х. Банальность зла. Эйхман в Иерусалиме. Москва : Европа, 2008. 424 с.

Bakhurst D. Consciousness and Revolution in Soviet Philosophy: From the Bolsheviks to Evald Ilyenkov. Cambridge : Cambridge University Press, 1991. 292 p.

Bazaluk O., Fatkhutdinov V., Svyrydenko D. The Potential of Systematization of the Theories of Education for Solving of Contradictions of Ukrainian Higher Education Development. Studia Warmińskie. 2018. Vol. 55. P. 63-79. DOI: https://doi.org/10.31648/sw.3062

Biesta G. How to exist politically and learn from it: Hannah Arendt and the problem of democratic education. Teachers College Record. 2010. Vol. 112. Iss. 2. P. 556-575.

Freire P. Pedagogy of the Oppressed. London : Penguin Books, 2017. 192 p.

Hodgson N., Vlieghe J., Zamojski P. Education and the Love for the World: Articulating a post-critical educational philosophy. Foro de Educación. 2018. Vol. 16. Iss. 24. P. 7-20. DOI: https://doi.org/10.14516/fde.576

Ильенков Э. В. Школа должна учить мыслить. Москва : МПСИ, 2002. 112 с.

Ильенков Э. Об идолах и идеалах. Киев : Час-Крок, 2006. 312 с.

Ilyenkov E. V. Dialectical Logic: Essays on its History and Theory / trans. by H. C. Creighton. New Delhi : Aakar Books, 2008. $372 \mathrm{p}$.

Ilyenkov E. Dialectics of the Ideal. Historical Materialism. 2012. Vol. 20. Iss. 2. P. 149-193. DOI: https://doi.org/ $10.1163 / 1569206 x-12341248$

Korsgaard M. T., Aldinger M. M. The Educator's Diary: Arendt and Kierkegaard on Progressivism and the Educational Relation. Educational Theory. 2018. Vol. 68. Iss. 4-5. P. 513-527. DOI: https://doi.org/ 10.1111/edth.12325

Levant A. E. V. Ilyenkov and Creative Soviet Theory: An Introduction to "Dialectics of the Ideal". Historical Materialism. 2012. Vol. 20. Iss. 2. P. 125-148. DOI: https://doi.org/10.1163/1569206x-12341247

Лобастов Г. В. Диалектика разумной формы и феноменология безумия. Москва : Русская панорама, 2012. $560 \mathrm{c}$.

Lotz C. Finding Evald Ilyenkov: How a Soviet philosopher who stood up for dialectics continues to inspire. MRonline, 2019. URL: https://mronline.org/2019/08/31/corinna-lotz-finding-ilyenkov-how-a-sovietphilosopher-who-stood-up-for-dialectics-continues-to-inspire/

Мамардашвили М. Сознание и цивилизация. Как я понимаю философию. Москва : Прогресс, 1992. C. $107-121$.

Мареев С. Н. Жить философией. Москва : Академический проект, 2015. 327 с. 
Minnich E. K. The Evil of Banality: On the Life and Death Importance of Thinking. Rowman \& Littlefield Publishers, 2016. $256 \mathrm{p}$.

Ницше Ф. Человеческое, слишком человеческое. Сочинения : в 2 т. Москва : Мысль, 1996. Т. 1. С. 231-490.

Oittinen V. Evald Ilyenkov, the Soviet Spinozist. Dialectics of the Ideal. Leiden : Brill, 2014. P. 107-122. DOI: https://doi.org/10.1163/9789004246928_006

Rancière J. The ignorant schoolmaster: Five lessons in intellectual emancipation / trans. by K. Ross. Stanford University Press, 1991. 176 p.

Щитцова Т. Какой кризис? Чья рациональность? Переосмысливая понятие натальности Ханны Арендт в свете современных вызовов для университетского образования. Ideology and Education in Post-Soviet Countries. 2019. № 2(13). C. 8-19.

Vivaldi G. A. Rethinking Soviet Marxism: The Case of Evald Ilyenkov. Historical Materialism. 2017. Vol. 25. Iss. 2. P. 180-195. DOI: https://doi.org/10.1163/1569206x-12341522

Vlieghe J., Zamojski P. Out of love for some-thing: An ontological exploration of the roots of teaching with Arendt, Badiou and Scheler. Journal of Philosophy of Education. 2019. Vol. 53. Iss. 3. P. 518-530. DOI: https://doi.org/10.1111/1467-9752.12375

Voznyak V. In search of "the third subject" of educational process. The Kazakh-American Free University Academic Journal. 2014. № 6. P. 109-116.

\section{В. С. ВОЗНЯК ${ }^{1 *}$, М. В. ЛІПІ ${ }^{2 *}$}

${ }^{1 *}$ Дрогобицький державний педагогічний університет імені Івана Франка (Дрогобич, Україна), ел. пошта volodimir.voznyak@gmail.com, ORCID 0000-0002-6877-3785

${ }^{2 *}$ Київський торговельно-економічний університет (Київ, Україна), ел. пошта pinli@ukr.net, ORCID 0000-0003-0940-088X

\section{ОСВІТА ЯК ПРОЛОМ МІЖ МИНУЛИМ І МАЙБУТНІМ}

Мета. У статті ставиться завдання осмислити феномен освіти в її антропологічному змісті, зіставляючи два варіанти аналітики кризового стану освіти, дані Ганною Арендт і Евальдом Ільєнковим. Теоретичний базис. Для реалізації цього завдання застосований метод поглибленого рефлексивного прочитання текстів, коли звичні академічні поняття розглядаються у новому контексті, визначеному аналітикою реальних суспільних проблем - в даному випадку мова йде про розвиток мислення не стільки як когнітивної здатності, скільки етико-онтологічної особливості людського буття. В такому випадку мислення виникає через його невидиму причетність однієї людини іншим, що констатує і Арендт, і Ільєнков. Наукова новизна. Новизна статті полягає у виявленні антропологічного виміру освіти і фіксації негативного впливу таких способів організації освітнього процесу, коли він підпорядкований диктату обставин, що склалися на даний момент, - обгрунтування цієї тези дане через виявлення співзвучності концепцій освіти Ганни Арендт і Евальда Ільєнкова. Висновки. Виявлене Ганною Арендт протистояння дії і мислення не можна розуміти як відрив мислення від дійсності, оскільки початковою реальністю для людини постає інша людина, а саме в мисленні людина входить в простір зустрічі з іншою людиною, стає на місце іншої людини і цим вперше знаходить своє місце в світі і стає сама собою, знаходячи образ людини. Так зрозуміла освіта не стає маніпулятивним дресуванням, але є дійсним народженням суб'єкта, який творить самого себе. Руйнування авторитету в сучасному світі супроводжується пошуками нових форм структурування загального простору діяльності людства, що можливо тоді, коли місце освіти визначається не соціальним середовищем, а їі відношенням до світу. Авторитет учителя дієвий, коли він спирається на відповідальність за світ, в який учитель вводить дитину та який відкриває їй. Відповідальність за світ й обумовлений нею авторитет пов’язані з любов’ю до світу. Тільки при наявності достатньої любові до світу людина здатна відповідати за нього.

Ключові слова: людина; освіта; мислення; суспільство; авторитет; відповідальність за світ

\section{В. С. ВОЗНЯК ${ }^{1 *}$, Н. В. ЛИПИН ${ }^{2 *}$}

\footnotetext{
1* Дрогобычский государственный педагогический университет имени Ивана Франко (Дрогобыч, Украина), эл. почта volodimir.voznyak@gmail.com, ORCID 0000-0002-6877-3785

${ }^{2 *}$ Киевский торгово-экономический университет (Киев, Украина), эл. почта pinli@ukr.net, ORCID 0000-0003-0940-088X

Creative Commons Attribution 4.0 International

doi: https://doi.org/10.15802/ampr.v0i17.206722 


\section{ОБРАЗОВАНИЕ КАК БРЕШЬ МЕЖДУ ПРОШЛЫМ И БУДУЩИМ}

Цель. В статье ставится задание осмыслить феномен образования в его антропологическом содержании, сопоставляя два варианта аналитики кризисного состояния образования, данные Ханной Арендт и Эвальдом Ильенковым. Теоретический базис. Для реализации данного задания применен метод углубленного рефлексивного прочтения текстов, когда привычные академические понятия рассматриваются в новом контексте, определяемом аналитикой реальных общественных проблем - в данном случае речь идет о развитии мышления не столько как когнитивной способности, сколько этико-онтологической особенности человеческого бытия. В таком случае мышление возникает через его невидимую сопричастность одного человека многим, что констатируется и Арендт, и Ильенковым. Научная новизна. Новизна статьи заключается в выявлении антропологического измерения образования и установлении негативного влияния таких способов организации образовательного процесса, когда он подчинен диктату обстоятельств, сложившихся на данный момент, - обоснование этого тезиса дано через выявление созвучности концепций образования Ханны Арендт и Эвальда Ильенкова. Выводы. Выявленное Ханной Арендт противостояние действия и мышления нельзя понимать как отрыв мышления от действительности, поскольку изначальной реальностью для человека предстает другой человек, а именно в мышлении человек входит в пространство встречи с другим человеком, становится на место другого человека и этим впервые обретает свое место в мире, становясь самим собой, обретая образ человека. Так понимаемое образование не становится манипулятивной дрессировкой, но есть действительным рождением субъекта как творящего самого себя. Разрушение авторитета в современном мире сопровождается поисками новых форм структурирования общего пространства деятельности человечества, что возможно тогда, когда место образования определяется не социальной средой, а его отношением к миру. Авторитет учителя действен, когда он опирается на его ответственность за мир, в который он вводит ребенка и который открывает ему. Ответственность за мир и обусловленный ею авторитет связаны с любовью к миру. Только при наличии достаточной любви к миру человек способен брать ответственность за него.

Ключевые слова: человек; образование; мышление; общество, авторитет; ответственность за мир

Received: 25.11.2019

Accepted: 12.05 .2020 